\title{
Influence of Biological, Social and Psychological Factors on Abnormal Eating Attitudes among Female University Students in Brazil
}

\author{
Larissa da Cunha Feio Costa', Francisco de Assis Guedes de Vasconcelos', and Karen Glazer Peres² \\ 'Programa de Pós-Graduação em Nutrição, Centro de Ciências da Saúde and ²Grupo de Estudos de Odontologia em Saúde Coletiva, \\ Programa de Pós-graduação em Saúde Pública, Universidade Federal de Santa Catarina, Florianópolis-Santa Catarina, Brazil
}

\begin{abstract}
The objective of the study was to estimate abnormal eating attitudes influenced by associated factors among female students of the Universidade Federal de Santa Catarina, Florianópolis, southern Brazil. Abnormal eating attitudes were investigated using the eating attitudes test (EAT-26), according to the presence (EAT+) and absence (EAT-) of symptoms in a sample of 220 students. The body-image was assessed by the bodyshape questionnaire (BSQ-34). Body mass index, body-fat percentage, waist-circumference, food intake (24-hour food recall), and socioeconomic characteristics (monthly household income, monthly per-capita income, and parental schooling) were also investigated. Statistical associations were tested by multivariate Poisson regression analysis. The prevalence of EAT+ and dissatisfaction with the body-image were 8.3\% [confidence interval (CI) 95\% 4.6-12.0] and 20.0\% (CI 95\% 14.7-25.3) respectively. Dissatisfaction with the body-image maintained its independent association with abnormal eating attitudes, indicating symptoms of anorexia nervosa. The results of this work highlight the importance of the planning of nutrition-education programmes in universities, aiming at assisting in the choices of food that comprise a healthful diet in a period of life of so many changes and decisions.
\end{abstract}

Key words: Anorexia nervosa; Attitudes; Body-image; Calorie intake; Cross-sectional studies; Eating disorders; Exploratory studies; Nutritional status; Brazil

\section{INTRODUCTION}

Eating disorders have received progressively more attention from health professionals since these can cause significant morbidity and mortality. Eating disorders have grown over recent decades, affecting distinct countries, cultures, and socioeconomic groups, to the extent of being recognized as one of the main public-health problems today $(1,2)$.

Anorexia nervosa as an eating disorder was first described in the 19th century, and being the first to be adequately classified and for which the operational criteria were recognized in the 1970s. It is

Correspondence and reprint requests should be addressed to (present address):

Dr. Francisco de Assis Guedes de Vasconcelos

Professor, Department of Nutrition

Centro de Ciências da Saúde

Universidade Federal de Santa Catarina

Campus Universitário Trindade

CEP: 88.040-970

Florianópolis-Santa Catarina

Brazil

Email: francisco.vasconcelos@pesquisador.cnpq.br

Fax: 55-48-37219542 categorized by, among other symptoms, rapid and deliberate loss of weight brought on by extremely strict diets, together with an unrestrained desire for thinness, gross distortion of the body-image, and changes in the menstrual cycle. It starts typically from mid- to late-adolescence, and around $95 \%$ of cases occur in women $(3,4)$.

The currently-accepted aetiological model is multi-factorial, with contributions coming from psychological, biological, familial and sociocultural factors, all of which interact to determine the mani-festation of anorexia nervosa(1-3).

Anorexia nervosa is an illness that leads to stunted growth, with excessive loss of weight and great physical and psychological impact. Numerous complications occur in affected individuals, including dehydration, cardiac impairment, disturbances of gastrointestinal motility, renal problems, infertility, hypometabolism, dental problems, anaemia, and osteoporosis. Patients who are in pre-puberty may exhibit a delay in sexual maturation, in physical development, and in growth and may not reach their expected height $(5,6)$. 
The factors triggering the eating disorders may be a significant event, such as loss of a loved one, separation, changes in family dynamics, organic disease, body-image disturbances, depression, anxiety, or even childhood trauma, such as sexual abuse. However, the way in which these factors act to cause the disorder remains to be clarified $(7,8)$.

Studies among university students have shown that they may compromise their nutritional status as a result of inadequate nutrition caused by dietary fads and skipping meals, among other factors (9). According to Cunha and Carrilho, the first year in higher education is a phase of challenge for students since it represents a period of development and academic adjustment, which demands adaptation and integration into the new environment (10). Vieira et al. found that $15 \%$ of university students began to exhibit health problems after entering university and attributed such disturbances to emotional causes, suggesting that the changes inherent in beginning university life could have affected the emotional balance and health in this group of individuals (11).

Despite the growing importance of the theme, studies among the university population are barely found, especially in developing countries. Epidemiological studies are important to define preventive health policies. The objectives of this study were to estimate the abnormal eating attitudes associated with biological, social and psychological factors and to describe the patterns of food intake by firstyear students at the Universidade Federal de Santa Catarina (UFSC), Brazil, in 2006.

\section{MATERIALS AND METHODS}

A cross-sectional, exploratory study was carried out, involving female adolescents and young adults $(n=935)$ in their first semester in 55 undergraduate courses at the UFSC. The UFSC, located in Florianópolis, southern Brazil, is considered one of the largest and most important federal universities in Brazil.

The following parameters were adopted to calculate the minimum sample size: $95 \%$ confidence level, a sample error of 2.85 percentage points, and a prevalence of symptoms of anorexia nervosa of $5.5 \%$ (12), which resulted in a sample size of 212 students. The calculations included an addition of $20 \%$ to compensate non-responses. The minimum required sample size was 254 students. The subjects were systematically selected from a complete list, including all female undergraduate students in an alphabetical order. Being pregnant or physically handicapped was considered an exclusion crite- rion. However, neither condition was observed in our study.

Data were collected during 5 June-8 December 2006.

\section{Independent variables}

The following variables were investigated: age; maternal and paternal schooling in terms of complete years of study; number of persons in the family; and monthly income of students and their domestic living arrangements.

The age of the subjects in years was calculated by subtracting the date of birth from the date of data collection, and the students were allocated in two age-groups (16-19 years and $\geq 20$ years).

The variables - maternal and paternal schoolingwere categorized as follows: 1-4 years, 5-8 years, 9-12 years, and more than 12 completed years of study.

The monthly per-capita income was obtained by dividing the self-reported monthly household income by the number of inhabitants in the family. The monthly household income was converted to minimum wages and then categorized as: less than $1,1.1-3,3.1-6$, and $\geq 6.1$. One minimum wage in Brazil corresponds to US\$201.14, based on the exchange rate as in December 2007 (US\$ 1=Reais 1.74).

Domestic arrangements were categorized as: living alone and with parents or colleagues. The practice of physical activity was classified as: no exercise undertaken, exercise undertaken less than three times a week, and exercising three or more times per week.

\section{Body-image}

The presence of worries concerning the body-image was investigated by means of the body-shape questionnaire (BSQ-34) - in the version translated into Portuguese by Cordás and Castilho (13). Students who scored from 0 to 80 points were classified as having no dissatisfaction with the bodyimage; 81 to 110 points slight worry; 111 to 140 moderate worry, and 141 to 204 points being classified as severe worry (14). The variable was later dichotomized as BSQ negative (BSQ-), for those who scored from 0 to 110 points, and BSQ positive (BSQ+) for those with a score above 111 points, for statistical analysis.

The BSQ is a self-applied test, which in its first validation study proved to be satisfactory for the assessment of concerns over the body-image, re- 
duced self-worth due to physical appearance, and the sensation of being fat and includes as a parameter the eating disorder inventory (EDI) subscale of dissatisfaction over body-image with a total score of EAT-26 (14).

Rosen et al. found a significant reliability coefficient of 0.88 for all the 34 items of psychometric characteristics on the BSQ-34 test (15). Similar results were observed in Brazil, after validation of the instrument in Portuguese (16).

\section{Food intake}

Food intake was examined by calculating the energy intake in kilocalories and that of macronutrients in grammes (proteins, lipids, and carbohydrates), collected through the 24-hour food recall. These data were recorded using the Nutwin software (version 2.5), developed by the Health Informatics Centre of the Universidade Federal de São Paulo, Brazil. The daily intake of each nutrient was analyzed, according to the recommendations of the dietary reference intakes for energy, carbohydrates, fibre, fat, protein, and acids (macronutrients) (17).

\section{Anthropometry}

The following measurements were taken: weight, height, waist-circumference, and bicipital, tricipital, subscapular and suprailiac skin-folds. These data were collected according to Lohman et al. (18). During data collection, the students were instructed to remove shoes, belts, heavy coats, jackets, and thick shirts.

The weight, height, and waist-circumference were measured only once while the tricipital, bicipital, subscapular and suprailiac skin-folds were obtained at three distinct time points, measured by one of the principal researchers who had been previously trained by a physical education professional with the aim of avoiding variability among the measurements.

The weight was determined using an electronic balance with a capacity of $180 \mathrm{~kg}$ and a precision of $100 \mathrm{~g}$. The height was obtained using a portable anthropometer with a bilateral scale from 35 to 213 $\mathrm{cm}$ and a resolution of $0.1 \mathrm{~cm}$. The waist-circumference was measured using an extendable metric tape with a precision of $1 \mathrm{~mm}$.

The skin-folds were measured with a Lange scientific adipometer with a precision of $1 \mathrm{~mm}$.

The weight and height of the subjects were employed to calculate the body mass index (BMI), diagnosed from the criterion recommended by the
World Health Organization (WHO) (19), which regards as underweight values for $\mathrm{BMI}<18 \mathrm{~kg} / \mathrm{m}^{2}$, with a eutrophic BMI between 18.5 and $25 \mathrm{~kg} / \mathrm{m}^{2}$, overweight BMI between 25 and $30 \mathrm{~kg} / \mathrm{m}^{2}$ and obese $\mathrm{BMI} \geq 30.0 \mathrm{~kg} / \mathrm{m}^{2}$.

The waist-circumference analysis followed the criteria recommended by the WHO (19), which consider a waist-circumference of $\geq 80 \mathrm{~cm}$ as a risk factor for abdominal obesity.

Measurements of bicipital, tricipital, subscapular and suprailiac skin-fold thickness were used for estimating the percentage of body-fat according to the formula of Durnin and Womersley (20). The classification followed the criteria proposed by Lohman (21), which consider eutrophic as a percentage of body-fat between 9 and 31, subnutrition equal to or less than 8 , and obesity as equal to or greater than 32 .

\section{Dependent variable: abnormal eating attitudes}

Abnormal eating attitudes were identified through the eating attitudes test (EAT-6) (22), translated into Portuguese by Nunes et al. (23). Students who scored 20 points or more on the EAT-26 were classified as individuals who exhibited dietary habits, suggestive of abnormality, i.e. symptomatic of anorexia nervosa (EAT+). Those who scored less than 20 were classified as symptom-free (EAT-).

The EAT-26 is a self-report instrument developed by Garner and Garfinkel to assess and identify abnormal eating standards (22). It is a psychometric test to measure symptoms of anorexia nervosa easily and quickly, thereby favouring early diagnosis and treatment and preventing the evolution of the disease (24).

In Brazil, the first translation was performed by Nunes et al., and this was tested in adolescents, aged 12-15 years, from public schools, with the result being considered to be adequate (23).

Magalhães and Mendonça performed a reliability test for the EAT-26, with a sample of 60 first-year students at a public university in Rio de Janeiro (25). The value of Kappa obtained for this instrument was 0.81 .

A pilot study was performed to test the instruments and identify the possible difficulties during the data-collection stage. Students from the nutrition course, who were not in their first semester, were assessed, enabling the optimization of anthropometric measurement techniques. 
Socioeconomic and dietary variables and information regarding dissatisfaction with the body-image and abnormal eating attitudes were collected using a questionnaire, filled up by the subjects receiving guidance on its correct completion.

The initial contact in performing the study was made through the course coordinators. Later, members of teaching staff were approached, and they gave a few minutes of their classes for an explanation of the study, followed by the presentation of objectives, subject-selection method, and research activities. Contact with the students was attempted on three occasions, and if there was no response, they were regarded as losses.

To avoid any possible bias in sampling, it was decided not to substitute the students who declined to participate or who did not attend for data collection.

\section{Statistical analysis}

Statistical calculations were performed using the Stata software (version 9.0). Descriptive statistics were calculated giving the distributions of relative and absolute frequencies for the variables of interest in the study and means and respective standard deviations for the quantitative variables. Pearson's chi-square test was applied to test the association between the independent variables and the outcome. To analyze the potential risk factors for the presence of abnormal eating attitudes, Poisson's multiple regression analysis was carried out, and the prevalence ratios with $95 \%$ confidence interval were obtained. A value of $\mathrm{p}<0.25$ in bivariate analysis was used for selecting variables for insertion in the multiple model, to control for possible confounding variables. Variables with $\mathrm{p}<0.05$ were retained in the final model.

\section{Ethics}

The Committee for Ethics in Research in Humans at the UFSC approved the research protocol.

\section{RESULTS}

The response rate achieved in the study was $86.6 \%$. The prevalence of abnormal eating attitudes among the first-year students was 8.3\% (CI 95\% 4.6-12.0).

Table 1 shows the general characteristics of the sampled subjects. The table abo shows that the mean age of the study subjects was 20.2 years (standard deviation 2.75).

The mean number of completed years of maternal and paternal schooling was 12 . However, when these data were categorized in years of schooling, it was revealed that $82.3 \%$ of mothers $(n=180)$ presented more than eight years of schooling while $78.3 \%$ of fathers $(n=170)$ had more than eight years of schooling.

The mean monthly per-capita income was Reais 1,128 (US\$ 648.27). The mean energy intake in the subjects was $1,780.86 \mathrm{kcal}$, with a standard deviation of 747.96 .

Table 2 presents the distribution of the independent variables, according to abnormal eating attitudes. The table shows that the group of first-year

\begin{tabular}{|c|c|c|c|}
\hline Variable & No. & Mean & $\begin{array}{l}\text { Standard } \\
\text { deviation }\end{array}$ \\
\hline Age (years) & 220 & 20.2 & 2.75 \\
\hline $\begin{array}{l}\text { Maternal } \\
\text { schooling (years } \\
\text { of study) }\end{array}$ & 219 & 12.3 & 4.07 \\
\hline $\begin{array}{l}\text { Paternal school- } \\
\text { ing (years of } \\
\text { study) }\end{array}$ & 217 & 12.6 & 4.52 \\
\hline $\begin{array}{l}\text { No. of family } \\
\text { members }\end{array}$ & 219 & 4.05 & 1.20 \\
\hline $\begin{array}{l}\text { Monthly } \\
\text { household in- } \\
\text { come (Reais*) }\end{array}$ & 190 & $4,469.90$ & $3,807.12$ \\
\hline $\begin{array}{l}\text { Monthly per- } \\
\text { capita income } \\
\left(\text { Reais*) }^{*}\right.\end{array}$ & 190 & $1,128.70$ & 889.46 \\
\hline Weight (kg) & 220 & 57.2 & 9.96 \\
\hline Height $(\mathrm{cm})$ & 220 & 163.7 & 6.52 \\
\hline $\begin{array}{l}\text { Body mass } \\
\text { index }\left(\mathrm{kg} / \mathrm{m}^{2}\right)\end{array}$ & 220 & 21.3 & 3.38 \\
\hline $\begin{array}{l}\text { Waist-circumf- } \\
\text { erence }(\mathrm{cm})\end{array}$ & 220 & 69.0 & 7.24 \\
\hline $\begin{array}{l}\text { Breastfeeding } \\
\text { (\%) }\end{array}$ & 220 & 28.0 & 4.10 \\
\hline $\begin{array}{l}\text { Energy intake } \\
\text { (kcal) }\end{array}$ & 219 & $1,780.86$ & 747.96 \\
\hline $\begin{array}{l}\text { Protein intake } \\
\text { (g) }\end{array}$ & 219 & 72.2 & 36.65 \\
\hline $\begin{array}{l}\text { Carbohydrate } \\
\text { intake }(\mathrm{g})\end{array}$ & 219 & 239.0 & 113.08 \\
\hline Lipid intake (g) & 219 & 62.1 & 35.76 \\
\hline
\end{tabular}


students dissatisfied with their body-image exhibited a significantly greater prevalence of abnormal eating attitudes (34.2\%) when compared with the group of students satisfied with their body-image (2.3\%).

The prevalence of abnormal eating attitudes was greater among those students whose monthly household income was found to be between 3.1 and 6.0 minimum salaries ( 1 minimum salary is equivalent to Reais 350.00 in May 2006, approximately US\$ 201.14) but this difference was not significant.

The highest prevalence of abnormal eating attitudes was found among students who lived alone (9.5\%) when compared with the other categories, although there was no association among these variables $(\mathrm{p}=0.907)$.

Furthermore, Table 2 shows that there was no significant relationship among the students positively identified with abnormal eating attitudes in terms of age, or whether the subject did or did not take part in physical activity.

The students considered to be eutrophic exhibited a greater prevalence of abnormal eating attitudes $(10.3 \%)$ when compared with those who were underweight (2.9\%).

The Poisson's multiple regression analysis demonstrated that the prevalence of abnormal eating attitudes was significantly higher among students with a low energy intake $(<2,200 \mathrm{kcal})$; however, this association lost its statistical significance in the adjusted analysis (Table 3). Dissatisfaction with the body-image was the only variable that presented an independent association with the presence of other variables analyzed. The students dissatisfied with their body-image exhibited prevalence of abnormal eating attitudes 13.5 times greater than those satisfied with their body-image.

\begin{tabular}{|c|c|c|c|}
\hline Variable & $\begin{array}{c}\text { Sample } \\
\text { distribution (\%) }\end{array}$ & $\begin{array}{c}\text { Anorexia } \\
\text { nervosa }(\%)\end{array}$ & $95 \% \mathrm{CI}$ \\
\hline \multicolumn{4}{|l|}{ Body-image } \\
\hline Body-shape questionnaire- & 80.0 & 2.3 & $0.0-4.5$ \\
\hline Body-shape questionnaire+ & 20.0 & 34.2 & $19.0-49.3$ \\
\hline \multicolumn{4}{|l|}{ Monthly household income (MS)* } \\
\hline$\geq 6.1$ & 72.1 & 5.8 & $1.9-9.8$ \\
\hline $3.1-6.0$ & 17.9 & 9.4 & $0.0-20.1$ \\
\hline $1.1-3.0$ & 10.0 & 5.3 & $0.0-16.3$ \\
\hline \multicolumn{4}{|l|}{ Living with } \\
\hline Relatives & 69.6 & 8.7 & $4.1-13.2$ \\
\hline Colleagues & 20.9 & 6.5 & $0.0-13.9$ \\
\hline Alone & 9.5 & 9.5 & $0.0-23.2$ \\
\hline \multicolumn{4}{|l|}{ Age (years) } \\
\hline Up to 19.9 & 57.7 & 9.5 & $4.3-14.7$ \\
\hline 20.0 or above & 42.3 & 6.6 & $1.3-11.8$ \\
\hline \multicolumn{4}{|l|}{ Physical activity (days per week) } \\
\hline$\geq 3$ & 27.3 & 8.3 & $1.1-15.1$ \\
\hline$<3$ & 16.8 & 13.9 & $2.0-25.8$ \\
\hline Not undertaken & 55.9 & 6.6 & $2.1-11.1$ \\
\hline \multicolumn{4}{|l|}{ Nutritional status (BMI) } \\
\hline Underweight $\left(<18.5 \mathrm{~kg} / \mathrm{m}^{2}\right)$ & 15.9 & 2.9 & $0.0-8.7$ \\
\hline Eutrophic (between 18.5 and $25 \mathrm{~kg} / \mathrm{m}^{2}$ ) & 72.3 & 10.3 & $5.4-15.1$ \\
\hline Overweight and obese $\left(\geq 25 \mathrm{~kg} / \mathrm{m}^{2}\right)$ & 11.8 & 3.9 & $0.0-11.8$ \\
\hline \multicolumn{4}{|l|}{ Energy intake (kcal) } \\
\hline$\geq 2,200$ & 85.8 & 5.4 & $2.1-8.7$ \\
\hline$<2,200$ & 14.2 & 22.6 & $7.0-38.2$ \\
\hline \multicolumn{4}{|c|}{$\begin{array}{l}{ }^{*} \text { MS=Minimum salary ( } 1 \text { minimum salary is equivalent to Reais } 350.00 \text { in May 2006, approximately } \\
\text { US\$ 201.14); BMI=Body mass index; CL=Confidence interval; UFSC=Universidade Federal de Santa } \\
\text { Catarina }\end{array}$} \\
\hline
\end{tabular}




\begin{tabular}{|c|c|c|c|c|}
\hline Variable & $\begin{array}{c}\text { Raw PR } \\
(95 \% \text { CI) }\end{array}$ & $\mathrm{p}$ value & $\begin{array}{c}\text { Raw PR } \\
(95 \% \text { CI) }\end{array}$ & $\mathrm{p}$ value \\
\hline Body-image & & $<0.001$ & & $<0.001$ \\
\hline Body-shape questionnaire- & 1.0 & & 1.0 & \\
\hline Body-shape questionnaire+ & $15.0(5.2-43.4)$ & & $13.5(3.5-51.7)$ & \\
\hline Monthly household income (MS) ${ }^{\dagger}$ & & 0.796 & & \\
\hline$\geq 6.1$ & 1.0 & & $e^{*}$ & \\
\hline $3.1-6.0$ & $1.6(0.4-5.7)$ & & & \\
\hline $1.1-3.0$ & $0.9(0.1-6.8)$ & & & \\
\hline Living with & & 0.907 & & \\
\hline Relatives & 1.0 & & $e^{*}$ & \\
\hline Colleagues & $0.8(0.2-2.5)$ & & & \\
\hline Alone & $1.1(0.3-4.5)$ & & & \\
\hline Age (years) & & 0.445 & $e^{*}$ & \\
\hline Up to 19.9 & 1.0 & & & \\
\hline 20.0 or over & $0.7(0.3-1.8)$ & & & \\
\hline Physical activity (days per week) & & 0.535 & $e^{*}$ & \\
\hline Undertaken $\geq 3$ & 1.0 & & & \\
\hline Undertaken $<3$ & $1.7(0.5-5.4)$ & & & \\
\hline Not undertaken & $0.8(0.3-2.3)$ & & & \\
\hline Nutritional status & & 0.202 & & 0.241 \\
\hline Underweight $\left(\mathrm{BMI}<18.5 \mathrm{~kg} / \mathrm{m}^{2}\right)$ & $0.3(0.1-2.0)$ & & $0.8(0.1-6.9)$ & \\
\hline Eutrophic $\left(\mathrm{BMI} \geq 18.5\right.$ and $<25 \mathrm{~kg} / \mathrm{m}^{2}$ ) & 1.0 & & 1.0 & \\
\hline Overweight and obese (BMI $\left.\geq 25 \mathrm{~kg} / \mathrm{m}^{2}\right)$ & $0.4(0.1-2.7)$ & & $0.3(0.1-4.7)$ & \\
\hline Energy intake (kcal) & & 0.002 & & 0.220 \\
\hline$\geq 2,200$ & 1.0 & & 1.0 & \\
\hline$<2,200$ & $4.2(1.7-10.2)$ & & $1.9(0.7-5.0)$ & \\
\hline
\end{tabular}

\section{DISCUSSION}

The results of the present study are based on a probabilistic representative sample of students entering the university in the first semester of 2006 in 55 undergraduate courses at the UFSC. The method adopted for the calculation and selection of the sample in the study reinforces the internal validity of the results. The sample investigated did not also differ significantly from the original population.

The prevalence of abnormal eating attitudes observed in the study $(8.3 \%)$ is within the range reported in other studies of the university population carried out in Brazil, which employed the EAT-26 to identify abnormal eating attitudes $(12,27)$. The worldwide prevalence of anorexia nervosa varies with the sample and the assessment methods. According to study data provided by the American Psychiatric Association (APA), the prevalence of anorexia was found to vary from $0.5 \%$ to $3.7 \%$ (5). In Brazil, studies have focused on the identification of abnormal eating attitudes in populations. A search for studies that investigated abnormal eating attitudes in Brazilian samples identified nine examples carried out during 2001-2006, in which the prevalence varied markedly from $4.7 \%$ to $21.1 \%$ $(6,12,27-30)$. The observed inconsistencies in the results of studies may be partially explained by the differences in age range, cultural background, and different levels of exposure of subjects to wellknown risk factors. In the municipality of Florianópolis (SC), the prevalence of abnormal eating attitudes was found to be $15.6 \%$ among female students aged 10-19 years (30).

It is important to emphasize that the students investigated had not been diagnosed with anorexia nervosa. The study merely estimated the presence of symptoms of this problem according to the EAT26, which identifies abnormal dietary standards. The EAT is a screening measure to help determine if individuals may present an eating disorder that requires professional attention. 
This probably explains why most (88.9\%) subjects with abnormal eating attitudes were classified as eutrophic. Moreover, the prevalence of abnormal eating attitudes was the highest among students with an energy intake below the average daily energy requirement for women in the age-group (31). This corroborates the findings of studies among university students which showed that they may compromise their nutritional status through inadequate nutrition characterized by dietary fads and skipped meals, among other factors (9).

Dissatisfaction with the body-image was the only variable that showed a significant association with the presence of abnormal eating attitudes, suggesting symptoms of anorexia nervosa. In the study by Alves et al., dissatisfaction with the body-image was also the strongest risk factor for the presence of abnormal eating attitudes (30). Similarly, Nunes et $a l$. reported that dissatisfaction with the body-image was the most important factor in the causation of eating disorders (28).

Some studies have drawn attention to an increase in the prevalence of eating disorders. Dunker and Phillippi observed that the increase in the prevalence of anorexia nervosa has occurred at the same time that a greater emphasis has been placed on female thinness as an expression of sexual attraction, in which society values attractiveness and thinness in particular, making obesity a highly-stigmatized and rejected condition (29). Furthermore, the model of beauty imposed by modern society, corresponding to a thin body, gives no consideration to aspects relating to health and differences in the physical make-up of the population. These observations help understand the reasons for dissatisfaction with body-image as felt by many women.

As a result, a distorted body-image has been recognized as one of the main factors in the causation of eating disorders. Fleitlich et al. noted that individuals with anorexia nervosa tend to see themselves as fat or out of proportion, despite being thin (1).

The factors that can interfere in perception the bodyimage include: social factors, sociocultural influences, media pressures, and the constant search for an ideal body associated with self-realization and happiness. All of these, including the distorted perception of the body-image, can interfere in the nutritional balance of an individual (32).

Contemporary Western societies are currently living under an ideal of thinness and of good physical shape. This standard imposes itself especially upon women, making physical appearance an important measure of personal worth. New and miraculous weight-loss diets proliferate while gyms offer countless exercise options and display the high technological investment in the development of exercise techniques (33).

Data found in the literature confirm that age-group (adolescents and young adults), sex (female) $(3,4)$ and dissatisfaction with the body-image are major factors associated with the presence of abnormal eating attitudes, the latter further corroborated by the results of this investigation. Furthermore, the university context is in itself a stressful factor that should be taken into consideration. In addition, many other psychological and emotional factors can play an important role in causing eating disorders that mimic symptoms of anorexia nervosa. There are undoubtedly a genetic predisposition, a range of environmental risk factors, and some information available with respect to the identity and relative importance of these contributions. However, virtually nothing is known about the individual causal processes involved, or about how they interact and vary across the development and maintenance of disorders (2).

According to Paxton, a trigger factor is usually present in the form of a significant event, such as loss of a loved one, separation, changes in family dynamics, organic disease, body-image disorders, depression, anxiety, and even childhood trauma, such as sexual abuse (7). However, the way in which these factors act to cause the disorder remains to be clarified.

The proportions of students according to type of undergraduate course, such as medicine $(4.5 \%)$, architecture (7.3\%), and librarianship (7.3\%), were similar in the sample and among the female students at the UFSC as a whole (3\%) (26). Therefore, these results should be extrapolated to other populations with caution. Another limitation is the cross-sectional design adopted in the study, which does not allow the identification of a causal relationship between the outcome and the independent variables.

As such, other variables need to be examined in further studies on this theme. Future, populationbased research should be carried out to determine whether the results obtained in our study are also found on a wider scale.

The results of this work highlight the importance of the planning of nutritional education programmes in universities, with the aim of increasing the understanding of nutrition and assisting in the choices of food that comprise a healthy diet in a period of life of so many changes and decisions. 


\section{ACKNOWLEDGEMENTS}

The authors are grateful to the students who participated in and, thereby, enabled this work to be carried out and to Monalisa Cenci for her contribution in carrying out the investigation, assisting in the preparation of the research project, and data collection.

\section{REFERENCES}

1. Fleitlich BW, Larino MA, Cobelo A, Cordás TA. Adolescent-onset anorexia nervosa. J Pediatr 2000;76(Suppl):S323-9.

2. Fairburn CG, Harrison PJ. Eating disorders. Lancet 2003;361:407-16.

3. American Psychiatric Association. Diagnostic and statistical manual of mental disorders DSM-IV. $4^{\text {th }}$ ed. Washington, DC: American Psychiatric Association 1994:23-8.

4. Cordás TA. Transtornos alimentares: classificação e diagnostico [Classification and diagnosis of eating disorders]. Rev Psiquiatr Clin 2004;31:154-7.

5. American Psychiatric Association. Practice guideline for the treatment of patients with eating disorders (revision). American Psychiatric Association Work Group on Eating Disorders. Am J Psychiatry 2000;157(1 Suppl):1-39.

6. Vilela JEM, Lamounier JA, Dellaretti Filho MA, Barros Neto JR, Horta GM. Transtornos alimentares em escolares [Eating disorders in school children]. J Pediatr 2004;80:49-54.

7. Paxton SJ. Current issues in eating disorders research. J Psychosom Res 1998;44:297-9.

8. Borges NJBG, Sicchieri JMF, Ribeiro RPP, Marchini JS, Santos JE. Transtornos alimentares: Quadro clínico [Eating disorders: clinical picture]. Rev Medicine 2006;39:340-8.

9. Fennell R. Health behaviors of students attending historically black colleges and universities: results from the National College Health Risk Behavior Survey. $J$ Am Coll Health 1997;46:109-17.

10. Cunha SM, Carrilho DM. O processo de adaptação ao ensino superior e o rendimento acadêmico [The influence of the undergraduate course adaptation process in the academic achievement]. Psic Esc Educ 2005;9:215-24.

11. Vieira VCR, Priore SE, Ribeiro SMR, Franceschini SCC, Almeida LP. Perfil socioeconômico, nutricional e de saúde de adolescentes recém-ingressos em uma universidade pública brasileira [Socioeconomic, nutritional and health profile of adolescents recently admitted to a Brazilian public university]. Braz J Nutr 2002;15:273-82.

12. Souza FGM, Martins MCR, Monteiro FCC, Menezes
Neto GC, Ribeiro IB. Anorexia e bulimia nervosa em alunas da faculdade de Medicina da Universidade Federal do Ceará [Anorexia and bulimia nervosa in female students from the medical school of the Federal University of Ceara]. Rev Psiquiatr Clín 2002;29:17280.

13. Cordás TA, Castilho S. Imagem corporal nos transtornos alimentares-Instrumento de avaliação: Body Shape Questionnaire [Body image on the eating disorders-evaluation instrument: Body Shape Questionnaire]. Psiquiatr Biol 1994;2:17-21.

14. Cooper P, Taylor MJ, Cooper Z, Fairburn CG. The development and validation of the body shape questionnaire. Int J Eat Disord 1987;6:485-94.

15. Rosen JC, Jones A, Ramírez E, Waxman S. Body shape questionnaire: studies of validity and reliability. Int $J$ Eat Disord 1996;20:315-9.

16. Di Pietro M, Silveira DX. Internal validity, dimensionality and performance of the body shape questionnaire in a group of Brazilian college students. Rev Bras Psiquiatr 2009;31:21-4.

17. Food and Nutrition Board. Dietary reference intakes for energy, carbohydrate, fiber, fat, fatty acids, cholesterol, protein and amino acids (macronutrients). Washington, DC: National Academy Press, 2005. $1357 \mathrm{p}$.

18. Lohman TG, Roche AF, Martorell R, editors. Anthropometric standardization reference manual. Champaign, IL: Human Kinetics Books, 1991:44-5.

19. World Health Organization. Obesity: preventing and managing the global epidemic: report of a WHO Consultation on Obesity. Geneva: World Health Organization, 2000. 253 p. (WHO technical report series no. 894).

20. Durnin JVGA, Womersley J. Body fat assessed from total body density and its estimation from skinfold thickness: measurements on 481 men and women aged from 16 to 72 years. Br J Nut 1974;32:77-97.

21. Lohman TG. Advances in body composition assessment. Champaign, IL: Human Kinetics Publishers, 1992. $150 \mathrm{p}$.

22. Garner DM, Garfinkel PE. The eating attitudes test: an index of the symptoms of anorexia nervosa. Psychol Med 1979;9:273-9.

23. Nunes MA, Bagatini L, Abuchaim AL, Kunz A, Ramos D, Silva JA. Distúrbios da conduta alimentar: considerações sobre o teste de atitudes alimentares (EAT) [Eating behaviours: considerations on the eating attitudes test (EAT)]. Rev ABPAPAL 1994;16:7-10.

24. Bighetti F. Tradução e validação do Eating Attitudes Test (EAT-26) em adolescentes do sexo feminino na cidade de Ribeirão Preto-SP [Translation and valida- 
tion of the eating attitudes test (EAT-26) in adolescent females in the city of Ribeirão Preto-SP]. Ribeirão Preto: Universidade de São Paulo, 2003. 101p. (Dissertation) (http://bases.bireme.br/cgibin/wxislind.exe/ iah/online/?IsisScript=iah/iah.xis\&src=google\&base= ADOLEC\&lang=p\&nextAction=lnk\&exprSearch $=43$ 3521\&indexSearch=ID, accessed on 13 April 2009).

25. Magalhães VC, Mendonça GAS. Transtornos alimentares em universitárias: estudo de confiabilidade da versão brasileira de questionários autopreenchíveis [Eating disorders in undergraduate students: study of the reliability of the Portuguese version of selfadministered questionnaires]. Rev Bras Epidemiol 2005;8:236-45.

26. Universidade Federal de Santa Catarina. Vestibular UFSC 2006-official report. (http://www.microsofttranslator.com/bv.aspx?ref=SERP\&br=ro\&mkt=enUS\&dl=en\&lp=pt_en\&a=http\%3a\%2f\%2fwww.vestibular2006.ufsc.br\%2frelatorio\%2findiceRelatorio. htm, accessed on 24 April 2009).

27. Bosi MLM, Luiz RR, Morgado CMC, Costa MLS, Carvalho RJ. Autopercepção da imagem corporal entre estudantes de nutrição no Rio de Janeiro. [Self-perception of body image among nutrition students in Rio de Janeiro]. Braz J Psychiatry 2006;55:34-40.

28. Nunes MA, Olinto MTA, Barros FB, Camey S. Influência da percepção do peso e do Índice de Massa Corporal nos comportamentos alimentares anormais.
[Influence of body mass index and body weight perception on eating disorders symptoms]. Braz J Psychiatry 2001;23:21-7.

29. Dunker KLL, Philippi ST. Hábitos e comportamentos alimentares de adolescentes com sintomas de anorexia nervosa [Food habits and feeding behavior in adolescents with symptoms of anorexia nervosa]. Braz J Nutr 2003;16:51-60.

30. Alves E, Vasconcelos FAG, Calvo MCM, das Neves J. Prevalência de sintomas de anorexia nervosa e insatisfação com a imagem corporal em adolescentes do sexo feminino do Município de Florianópolis, Santa Catarina, Brasil [Prevalence of symptoms of anorexia nervosa and dissatisfaction with body image among female adolescents in Florianópolis, Santa Catarina State, Brazil]. Rep Pub Health 2008;24:503-12.

31. National Research Council. Food and Nutrition Board. Recommended dietary allowances. $10^{\text {th }}$ ed. Washington, DC: National Academy of Science, 1989. $302 \mathrm{p}$.

32. Conti MA, Frutuoso MF, Gambardella AMD. Excesso de peso e insatisfação corporal em adolescents [Obesity and body dissatisfaction amongst adolescents]. Braz J Nutr 2005;18:491-7.

33. Morgan CM, Azevedo AMC. Aspectos sócio-culturais dos transtornos alimentares [Socio-cultural aspects of food disorders]. Psychiatry on-line Brazil 1998;3. (http://www.priory.com/psych/culture.htm, accessed on 30 May 2006). 